$\Theta$

\title{
ALLELOCHEMICALS FROM CASTANEA SATIVA MILL.: PLANT-R00T ENVIRONMENT INTERACTIONS
}

\author{
Pavliuchenko Nataliia*1 , Grygorieva Olga $^{2}$, Klymenko Svitlana ${ }^{2}$ \\ ${ }^{1}$ M.M. Gryshko National Botanical Garden of National Academy of Sciences of Ukraine, Department \\ of Allelopathy, Kyiv, Ukraine \\ ${ }^{2}$ M.M. Gryshko National Botanical Garden of National Academy of Sciences of Ukraine, Department of \\ Fruit Plants Acclimatization, Kyiv, Ukraine
}

Received: 24. 10. 2019 Revised: 30. 10. $2019 \quad$ Published: 28. 11. 2019

The paper is devoted to the study of the allelopathic properties of the root environment of Castanea sativa Mill. plants of different ages under the conditions of introduction. The objects of the research were 10 and 40-year-old plants of C. sativa, which are growing in Forest-Steppe of Ukraine in M.M. Gryshko National Botanical Garden of National Academy of Sciences of Ukraine. Rhizosphere soil samples were collected at $0-30 \mathrm{~cm}$ layer. The fallow soil was used as a control. Allelopathic and biochemical analyzes of root environment of $C$. sativa were conducted in dynamics during the growing season. Allelopathic activity of the root environment was studied by direct bioassay method. The soil redox potential (Eh) was measured by potentiometric technique. Phenolic compounds were extracted from the soil by desorption method using an ion exchanger $\mathrm{KU}-2-8\left(\mathrm{H}^{+}\right)$. Allelopathic analysis of the root environment of chestnut plants showed phytotoxicity within the range of 19.9-61.9\% compared with control. Phytotoxicity increased under the influence of 40 -year-old plants. The redox status of the root environment of $C$. sativa was characterized by the predominance of reducing conditions, the intensity of which increased under the influence of the older plants. The values of redox potential of the rhizosphere soil were 1.2-3.5 times lower than control. This indicates the accumulation of mobile organic compounds in the root environment of $C$. sativa. The content of phenolic compounds in the root environment of $C$. sativa was 1.4-2.5 times higher than control. The accumulation of organic compounds of phenolic nature caused obviously an increase in the phytotoxicity of the root environment of $C$. sativa along with the age of the plants. Thus, the seasonal dynamics of allelopathic activity, redox conditions, and the content of phenolic allelochemicals in the root environment of $C$. sativa depended on the age of plants.

Keywords: Castanea sativa, root environment, allelopathic activity, phenolic allelochemicals, redox potential

*Corresponding author: Nataliia Pavliuchenko, M.M. Gryshko National Botanical Garden of National Academy of Sciences of Ukraine, Timiryazevska 1, 01014 Kyiv, Ukraine $\triangle$ npavliuch@gmail.com 


\section{Introduction}

Sweet chestnut (Castanea sativa Mill., Fagaceae family) is a valuable food, ornamental, honey and medicinal plant. C. sativa is a rich source of broad-spectrum bioactive compounds and nutrients, that give it medicinal properties (Leonardi et al., 1996; Chiarini et al., 2013; Fuente-Maqueda, 2018; Grygorieva et al., 2018; Cerulli et al., 2018; Esposito et al., 2019). C. sativa exhibits antibacterial, antifungal, antioxidant and cardioprotective effects (Basile et al., 2000; Chiarini et al., 2013; Esposito et al., 2019). C. sativa pollen is highly prized for its nutritional, healing and dietary qualities (Žiarovská et al., 2015). C. sativa is an important source of commercially extracted tannins (Melicharová and Vizoso-Arribe, 2012). C. sativa is widely used for the commercial production of nuts, used both in fresh and in the form of paste, puree, crumb, flour and confectionery (Demiate et al., 2001; Melicharová and VizosoArribe, 2012; Grygorieva et al., 2017). Chestnut is a moderate heliophile species and has rather high photosynthetic rates, contributing to its fast growth (Covone and Gratani, 2006). In connection with this, $C$. sativa is cultivated for high-quality hardwood timber, used in the furniture industry, as structural material for buildings, as well as for fences, parquets, shelves for wine barrels and baskets (Melicharová and Vizoso-Arribe, 2012).

C. sativa grows in nature mainly in the Mediterranean and Atlantic regions of Europe, Asia Minor and North Africa (Villani et al., 1994; Rubio et al., 2002; Conedera et al., 2004; Krebs et al., 2004; Dengiz et al., 2011; Melicharová and Vizoso-Arribe, 2012; Miguez-Soto et al., 2019). C. sativa is spread in Ukraine predominantly in the Precarpathian and Transcarpathian regions. Recently, the economic efficiency of using of $C$. sativa in natural habitats significantly reduced as a result of damage from pests and diseases, and the effects of global climate change (Melicharová and Vizoso-Arribe, 2012; Conedera et al., 2016; Miguez-Soto et al., 2019). Therefore, it is extremely important to cultivate $C$. sativa outside the natural range to preserve its gene pool.

The success of the introduction of new plant species is largely determined by the allelopathic factor, that regulates the processes of growth and development both in plantings of different plant species and in monoculture (Zaimenko et al., 2017; Pavliuchenko et al., 2018). The study of species interactions between C. sativa and Pseudotsuga menziesii (Mirb.) Franco showed, that mixed plantations had a positive effect on the productivity of the chestnut (Nunes et al., 2011). The ethyl acetate soluble fraction of the aqueous extract from $C$. sativa leaves showed potent allelopathic effect on Raphanus sativus seed germination, root and epicotyl growth (Basile et al., 2000).

The purpose of the work was to investigate the allelopathic properties of the root environment of $C$. sativa plants of different ages under the conditions of introduction.

\section{Material and methodology}

\section{Plant material and soil source}

The objects of the research were 10 and 40-year-old plants of $C$. sativa, which are growing in Forest-Steppe of Ukraine in M.M. Gryshko National Botanical Garden of National Academy of 
Sciences of Ukraine. Rhizosphere soil samples were collected at 0-30 cm layer. The fallow soil was used as a control. The soil is a grey forest. Allelopathic and biochemical analyses were conducted in dynamics on phases of plant development during flowering (I), fruit formation (II) and the end of the growing season (III).

\section{Allelopathic activity}

Allelopathic activity of the root environment was studied by direct bioassay method on cress (Lepidium sativum L.) root growth (Grodzinskij et al., 1990).

\section{Biochemical analyses}

The redox potential (Eh) was measured in soil suspension modelling soil solution at the soil to distilled water ratio as $1: 1$ by potentiometric technique (Labuda and Vetchinnikov, 2011; Fiedler et al., 2007). Phenolic compounds were extracted from the soil by desorption method using an ion exchanger KU-2-8 ( $\left.\mathrm{H}^{+}\right)$(Grodzinskij et al., 1988).

\section{Data analysis}

Experimental data were statistically analyzed using the software package Microsoft Excel.

\section{Results and discussion}

Allelopathic analysis of the root environment of chestnut plants showed phytotoxicity within the range of 19.9-61.9\% compared with control (Figure 1). Phytotoxicity increased under the influence of 40-year-old plants. The allelopathic activity of the root environment was maximal at the end of the growing season, which is obviously due to the release of organic compounds from plant residues.

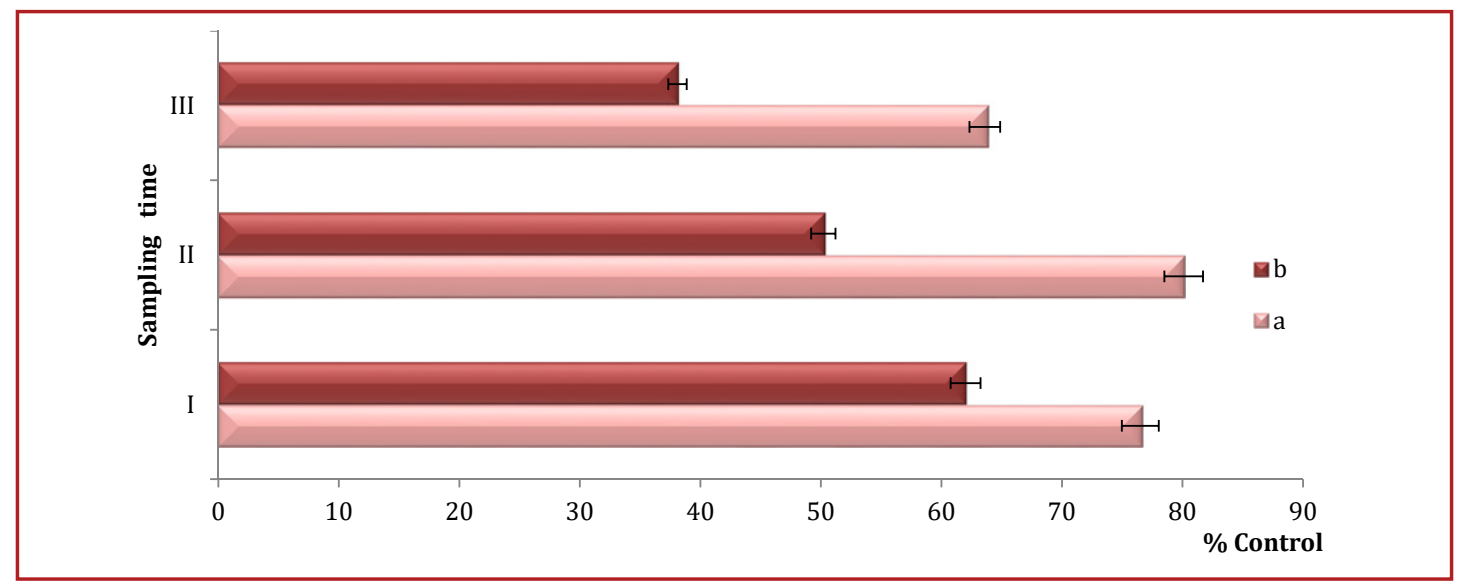

Figure 1 Allelopathic activity of the root environment of Castanea sativa (bioassay - root growth of Lepidium sativum L.) (\%) control a - 10-year-old plants; b - 40-year-old plants

The degradation of toxic organic compounds depends on their innate chemical properties and environmental conditions (Fiedler et al., 2007). Thus, anaerobic conditions can enhance the 
solubility of toxic forms of organic compounds (Fiedler et al., 2007). Therefore, it is extremely important to know the nature of oxidation-reducing processes in the root environment.

The biochemical status of the root environment of $C$. sativa was assessed by the values of the redox potential. The redox status of the root environment of $C$. sativa was characterized by the predominance of reducing conditions, the intensity of which increased under the influence of the older plants (Figure 2).

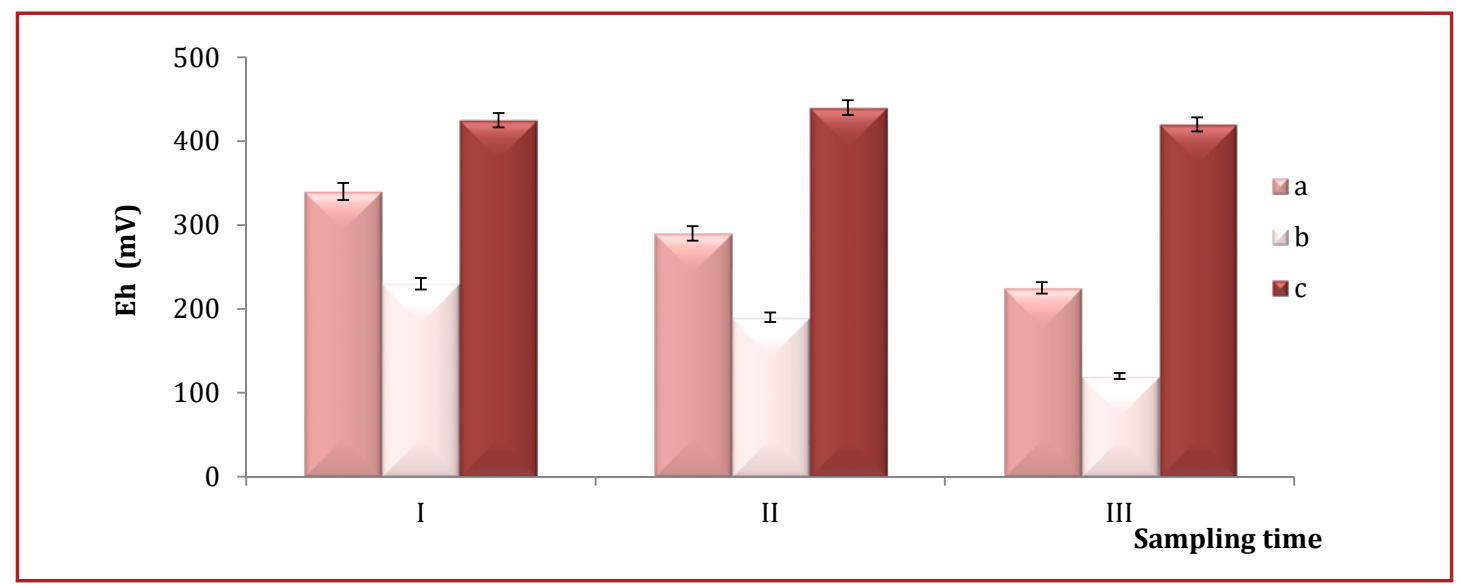

Figure 2 The redox potential (Eh) of Castanea sativa rhizosphere soil (mV) a - 10-year-old plants; b - 40-year-old plants; c - control

At the same time, weakly oxidizing conditions in the control were detected. The values of the redox potential of the rhizosphere soil were 1.2-3.5 times lower than control. This indicates the accumulation of mobile organic compounds, which may have allelopathic properties.

It is known that phenolic compounds are one of the main classes of allelochemicals, since they influence on various physiological and biochemical processes of plants, regulate species interactions in both mixed and pure plantations (Li et al., 2010). Therefore, it was necessary to analyze the content of phenolic allelochemicals in the root environment of $C$. sativa.

The content of phenolic compounds in the root environment of $C$. sativa was 1.4-2.5 times higher than control (Figure 3). The concentration of phenolic compounds was higher in the root environment of the older $C$. sativa plants. The dynamics of accumulation of phenolic compounds in the rhizosphere soil has shown a tendency to gradually increase their content during the growing season.

Litterfall, wood, and leaves of C. sativa are an important source of organic matter and nutrients for the soil (Leonardi et al., 1996; Nunes et al., 2011). However, secondary metabolites, including phenolic nature, from different tree organs can also be released into the rhizosphere soil of $C$. sativa through root exudates, leaching, and decay. C. sativa contains a significant pool of phenolic compounds, in particular tannins and flavonoids (Chiarini et al., 2013; FuenteMaqueda, 2018; Esposito et al., 2019). Tannins and phenolic compounds characterized in C. sativa bark, including ellagic acid, gallic acid, and ellagitannins (vescalin, castalin, 
vescalagin, and castalagin), were reported (Chiarini et al., 2013). Other minor compounds from C. sativa bark, detected in trace levels, 5-o-galloylhamamelose (3.5-dimethoxy-4hydroxyphenol)-1-o- $\beta$-D-(6-o-galloyl)-glucoside isomer, $m$-digallic acid, kurigalin isomer, and chestanin were reported (Chiarini et al., 2013). Glucose esters with gallic acid (-mono, -di, and -trigalloylglucose), ellagitannins (vescalagin/castalagin), phenolic acids (gallic, ellagic, protocatechuic, chlorogenic acid), flavonoids (apigenin, quercetin, and quercetin 3-O-glucoside) has been identified in chestnut burs (Esposito et al., 2019). A methanol extract of the leaves of $C$. sativa contained as main compounds crenatin, chestanin, gallic acid, cretanin, 5-O- $p$-coumaroylquinic acid, $p$-methyl gallic acid and quercetin-3-O-glucoside (Cerulli et al., 2018). HPLC analysis of ethyl acetate fraction of $C$. sativa leaf aqueous extract identified the following flavonoids: rutin, hesperidin, quercetin, apigenin, kaempferol, morin, galangin, and naringin (Basile et al., 2000). The ethyl acetate extract from $C$. sativa leaves and therein identified apigenin, rutin, quercetin inhibited seed germination, root and epicotyl growth of Raphanus sativus (Basile et al., 2000).

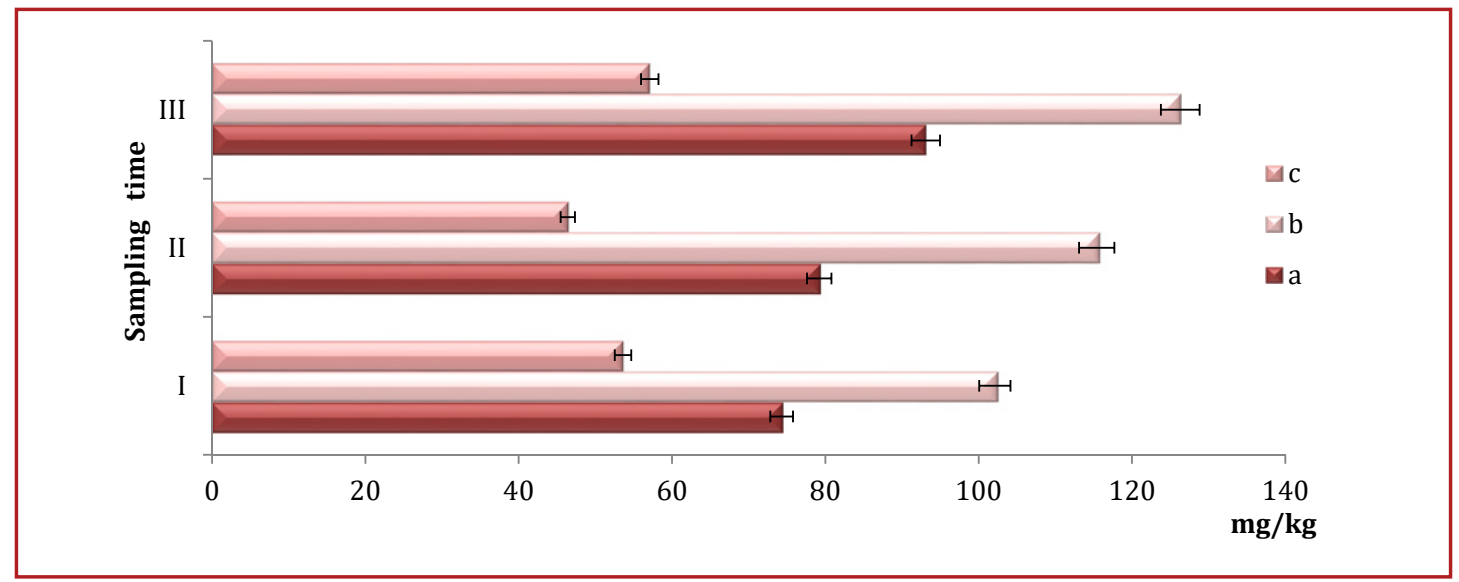

Figure 3 Phenolic compounds content in the root environment of Castanea sativa (mg/kg) a - 10-year-old plants; b - 40-year-old plants; c - control

In connection with the foregoing, it can be stated that the accumulation of phenolic allelochemicals obviously leads to increased phytotoxicity of the root environment of the older C. sativa plants.

\section{Conclusions}

The accumulation of organic compounds of phenolic nature caused obviously an increase in the phytotoxicity of the root environment of $C$. sativa along with the age of the plants. Thus, the seasonal dynamics of allelopathic activity, redox conditions, and the content of phenolic allelochemicals in the root environment of $C$. sativa depended on the age of plants. 


\section{References}

BASILE, A., SORBO, S., GIORDANO, S., RICCIARDI, L., FERRARA, S., MONTESANO, D., COBIANCHI, R.C., VUOTTO, M.L., FERRARA, L. 2000. Antibacterial and allelopathic activity of extract from Castanea sativa leaves. In Fitoterapia, vol. 71(1), p. 110-116. https://doi.org/10.1016/ S0367-326X(00)00185-4

CERULli, A., MASUllO, M., MARI, A., BALATO, A., FILOSA, R., LEMBO, S., NAPOLITANO, A., PIACENTE, S. 2018. Phenolics from Castanea sativa leaves and their effects on UVB-induced damage. In Natural Product Research, vol. 32(10), p. 1170-1175. https://doi.org/10.1080/14786419.2017.1331225

CHIARINI, A., MICUCCI, M., MALAGUTI, M., BUDRIESI, R., IOAN, P., LENZI, M., FIMOGNARI, C., TOSCHI, T.G., COMANDINI, P., HRELIA, S. 2013. Sweet chestnut (Castanea sativa Mill.) bark extract: cardiovascular activity and myocyte protection against oxidative damage. In Oxidative Medicine and Cellular Longevity, vol. 2013, Article ID 471790, 10 p. https://doi.org/10.1155/2013/471790

CONEDERA, M., KREBS, P., TINNER, W., PRADELLA, M., TORRIANI, D. 2004. The cultivation of Castanea sativa (Mill.) in Europe, from its origin to its diffusion on a continental scale. In Vegetation History and Archaeobotany, vol. 13(3), p. 161-179. https://doi.org/10.1007/s00334-004-0038-7

CONEDERA, M., TINNER, W., KREBS, P., DE RIGO, D., CAUDULLO, G. 2016. Castanea sativa in Europe: distribution, habitat, usage and threats. In European Atlas of Forest Tree Species. Luxembourg: Publ. Off. EU, p. 78-79. Available at: http://ies-ows.jrc.ec.europa.eu/efdac/download/Atlas/pdf/ Castanea_sativa.pdf

COVONE, F., GRATANI, L. 2006. Age-related physiological and structural traits of chestnut coppices at the Castelli Romani Park (Italy). In Annals of Forest Science, vol. 63(3), p. 239-247. https://doi. org/10.1051/forest:2006002

DENGIZ, O., IC, S., SARİGLU, F.E. 2011. Physico-chemical and morphological properties of soils for Castanea sativa in the Central Black Sea Region. In International Journal of Agricultural Research, vol. 6(5), p. 410-419. https://doi.org/10.3923/ijar.2011.410.419

DEMIATE, I.M., OETTERER, M., WOSIACKI, G. 2001. Characterization of chestnut (Castanea sativa, Mill.) starch for industrial utilization. In Braz. arch. biol. technol., vol. 44(1), p. 69-78. https://doi. org/10.1590/S1516-89132001000100010

ESPOSITO, T., CELANO, R., PANE, C., PICCINELli, A.L., SANSONE, F., PICERNO, P., ZACCARDELLI, M., AQUINO, R.P., MENCHERINI, T. 2019. Chestnut (Castanea sativa Miller) burs extracts and functional compounds: UHPLC-UV-HRMS profiling, antioxidant activity, and inhibitory effects on phytopathogenic fungi. In Molecules, vol. 24(2), p. 302. https://doi.org/10.3390/ molecules24020302

FIEDLER, S., VEPRASKAS, M.J., RICHARDSON, J.L. 2007. Soil redox potential: importance, field measurements and observations. In Advanced in Agronomy, vol. 94, p. 1-54. https://doi. org/10.1016/S0065-2113(06)94001-2

FUENTE-MAQUEDA, F. 2018. Fenoles en Castanea sativa Mill.: desde el monte a la industria: tesis doctoral [Phenols in Castanea sativa Mill.: from forest to industry: doctoral thesis]. Oviedo, Espana: Departamento de Biologia de Organismos y sistemas, Universidad de Oviedo. 216 p. Available at: http://digibuo.uniovi.es/dspace/bitstream/10651/48995/1/TD_JoseFranciscoFuente.pdf [In Spanish].

GRODZINSKIJ, A.M., GOROBEC, S.A., KRUPA, L.I. 1988. Rukovodstvo po primeneniju biohimicheskih metodov $v$ allelopaticheskih issledovanijah pochv [Guidance on the application of biochemical methods in allelopathic studies of soil]. Kyiv : CRBS AN USSR. 18 p. [In Russian].

GRODZINSKIJ, A.M., KOSTROMA, E.Ju., SHROL, T.S., HOHLOVA, I.G. 1990. Prjamye metody biotestirovanija pochvy i metabolitov mikroorganizmov [Direct bioassay methods of soil and microorganisms metabolites]. In Allelopatija i produktivnost' rastenij: Sbornik nauchnyh trudov [Allelopathy and plant productivity: Collection of scientific papers]. Kyiv : Naukova dumka, p. 121-124 [In Russian]. 
GRYGORIEVA, O., KLYMENKO, S., BRINDZA, J., SCHUBERTOVÁ, Z., NIKOLAIEVA, N., ŠIMKOVÁ, J. 2017. Morphometric characteristics of sweet chestnut (Castanea sativa Mill.) fruits. In Potravinarstvo Slovak Journal of Food Sciences, vol. 11(1), p. 288-295. https://doi.org/10.5219/684

GRYGORIEVA, O.V., KLYMENKO, S.V, TESLYUK, M.G., ONYSCHUK, L.M. 2018. Variability of morphological parameters and determination of volatile organic compounds of sweet chestnut (Castanea sativa Mill.) genotypes fruits. In Introdukciia Roslyn, no 2, p. 74-83. https://doi.org/10.5281/ zenodo.2230369

KREBS, P., CONEDERA, M., PRADELLA, M., TORRIANI, D., FELBER, M., TINNER, W. 2004. Quaternary refugia of the sweet chestnut (Castanea sativa Mill.): an extended palynological approach. In Vegetation History and Archaeobotany, vol. 13(3), p. 145-160. https://doi.org/10.1007/ s00334-004-0041-z

LABUDA, S.Z., VETCHINNIKOV, A.A. 2011. Soil susceptibility on reduction as an index of soil properties applied in the investigation upon soil devastation. In Ecological Chemistry and Engineering $S$, vol. 18(3), p. 333-344. Available at: https://pdfs.semanticscholar.org/a64a/ e32d59adc398a9a00d46d89583e7d6813676.pdf

LEONARDI, S., SANTA REGINA, I., RAPP, M., GALLEGO, HA, RICO, M. 1996. Biomass, litterfall and nutrient content in Castanea sativa coppice stands of southern Europe. In Ann. For. Sci., vol. 53(6), p. 10711081. https://doi.org/10.1051/forest:19960603

LI, Z.-H., WANG, Q., RUAN, X., PAN, C.-D., JIANG, D.-A. 2010. Phenolics and plant allelopathy. In Molecules, vol. 15(12), p. 8933-8952. https://doi.org/10.3390/molecules15128933

MELICHAROVÁ, L., VIZOSO-ARRIBE, 0. 2012. Situation of sweet chestnut (Castanea sativa Mill.) In Spain, Galicia: a review. In Scientia Agriculturae Bohemica, vol. 43(2), p. 78-84. Available at: https://sab. czu.cz/en/r-8044-archive/r-8060-2012-issues/r-11656-02-2012

MIIGUEZ-SOTO, B., FERNANDEZ-CRUZ, J., FERNANDEZ-LOPEZ, J. 2019. Mediterranean and Northern Iberian gene pools of wild Castanea sativa Mill. are two differentiated ecotypes originated under natural divergent selection. In PLoS ONE, vol. 14(2), e0211315. https://doi.org/10.1371/journal. pone.0211315

NUNES, L., COUTINHO, J., NUNES, L.F., REGO, F.C., LOPES, D. 2011. Growth, soil properties and foliage chemical analysis comparison between pure and mixed stands of Castanea sativa Mill. and Pseudotsuga menziesii (Mirb.) Franco, in Northern Portugal. In Forest Systems, vol. 20(3), p. 496507. https://doi.org/10.5424/fs/20112003-11104

PAVLIUCHENKO, N., KLYMENKO, S., DOBROSKOK, V., KRUPA, S. 2018. Allelopathic and biochemical characteristics of the root environment of Asimina triloba (L.) Dunal. In Agrobiodiversity for Improving Nutrition, Health and Life Quality, no. 2. Nitra: Slovak University of Agriculture, p. 62-68. ISBN 978-80-552-1970-7. https://doi.org/10.15414/agrobiodiversity.2018.2585-8246.062-068

RUBIO, A., ElENA, R., SANCHEZ, O., BLANCO, A., SANCHEZ, F., GOMEZ, V. 2002. Soil evaluation for Castanea sativa afforestation in Northeastern Spain. In New Forests, vol. 23(2), p. 131-141. https:// doi.org/10.1023/A:1015624014868

VILLANI, F., PIGLIUCCI, M., CHERUBINI, M. 1994. Evolution of Castanea sativa Mill. in Turkey and Europe. In Genet. Res. Camb., vol.63(2), p. 109-116. https://doi.org/10.1017/S0016672300032213

ZAIMENKO, N., PAVLIUCHENKO, N., KLYMENKO, S., DOBROSKOK, V., KRUPA, S. 2017. Stabilization by silicon compounds of the allelopathic soil regime under perennial fruit plantations. In Agrobiodiversity for Improving Nutrition, Health and Life Quality. Nitra: Slovak University of Agriculture, p. 533-536. ISBN 978-80-552-1726-0. https://doi.org/10.15414/ agrobiodiversity.2017.2585-8246.533-536

ŽIAROVSKÁ, J., GRYGORIEVA, O., ZELEŇÁKOVÁ, L., BEŽO, M., BRINDZA, J. 2015. Identification of sweet chesnut pollen in bee pollen pellet using molecular analysis. In Potravinarstvo Slovak Journal of Food Sciences, vol. 9(1), p. 352-357. https://doi.org/10.5219/497 